\title{
Fish Pathogenic Bacteria (Aeromonas Hydrophilia) Induced Histopathological Attributes in the Spleen And Lymph-Nodes of Swiss Albino Mice
}

\author{
A. K. Pramanik ${ }^{a}$ and K. B. Santra ${ }^{b *}$ \\ ${ }^{a}$ Research Scholar, Department of Zoology, Endocrinology Laboratory, University of Kalyani, Kalyani, \\ Nadia and Department of Zoology, Daulatour High School (H.S.) Daulatpur, West Bengal, India.
}

\begin{abstract}
The effect of fish pathogenic bacteria, Aeromonas hydrophilia on the spleen and lymph-nodes of male Swiss albino mice has been investigated and examined histopathologically. Morphological and histological changes on the 7th, 14th, 21st, and 30th day of infection were noticed. Time exposure showed no significant difference in body weight between control and treated mice but the value showed a tendency towards increment. Spleen weight was increased significantly $(p<0.001)$ at 14 th and 21 st days of post treated mice. The treatment groups showed hepatocellular necrosis of spleen and other immuno- responsive tissue like lymph-node of mice also. The damaging nature of the immuno-responsive tissues of mice to the pathogenesis of bacteria, Aeromonas hydrophilia is provoked in the results obtained.
\end{abstract}

Key words : Aeromonas hydrophilia, Spleen, Lymph-nodes, Hepatocellular necrosis

\section{Introduction}

Epizootic ulcerative syndrome is one kind of disease that is generally found in fishes. It is caused by the infection of various types of bacteria, viruses and fungi. This type of disease has been noticed in many states of India such as West Bengal, Orissa, Bihar, Utter Prodesh, Sikkim and Kerala (Pal and Pradhan, 1990; Pradhan et al., 1991, Harris et al., 1992). Aeromonas hydrophila and other motile aeromonads are among the most common bacteria in freshwater habitats throughout the world. Fish with only cutaneous infections may have several types of concealed lesions including increased amounts of lipofuscin and haemosiderin in the liver and spleen; however, most visceral organs were not necrotic (Ventura and Grizzle 1988). In some vertebrates Aeromonas hydrophilia cause a variety of disease, for example, stomatitis and pneumonia (Hey wood, 1968), septicemia (Camin, 1948) in snakes, ulcerative dermatitis and pneumonia in bottle nosed dolphin (Cusick and Bullock, 1973). More over, the bacterium has been reported to cause the death of large number of fish and alligators in lake Apopka, Florida (Shoots et al., 1972). Natural and experimental aeromonas infections in fish, amphibia and reptiles are associated with haematological (Roberts, 1978) and histopathological changes (Huizinga et al., 1979). The pathogepesis of infections in poikilotherms and man are incompletely understood but may be associated with the release of toxins (Ketover et al., 1973). The effects of $A$. hydrophila toxins produced in vitro have been studied in rats (Ljungh and Kronevi, 1982) and mice (Rigney et al., 1978). Aeromonas has been reported to cause bovine abortion (Wohlgemith et al., 1972) and septicemia in dog (Pierce et al., 1973). Aeromonas hydrophila is also known as an opportunistic pathogenic bacterium, meaning they only infect hosts with weakened immune responses (Chopra et al., 2000).

Several authors studied the histopathological changes of some organs in different vertebrates by inoculation of pure and mixed culture of bacteria (Price and Callum, 1987; Lai et al., 1991). But sufficient information are lacking regarding the effects of Aeromonas bacteria on the immune responsive tissue of mammals. So the present study was initiated to show the effect of fish pathogenic bacteria on the immune responsive tissue, like spleen and lymph node of mice.

\section{Materials and Method}

\section{Animals and treatment}

Male Swiss mice used in the present study were purchased from the local animal dealer. All animals were kept in specially made aluminum cages (6mice/cage) and allowed to acclimatize for 7 days prior to experimental uses. The animals were given food and water add libitum and were maintained at $12 \mathrm{~h} / 12 \mathrm{~h}$ light/dark conditions. A total of 6 animals 
were randomly assigned to each of the five treatment groups. Group A, served as control and Groups B, C, D, and E were kept as the treated groups. All the experimental groups (B to E) were inoculated with intra peritoneal injection of $0.1 \mathrm{ml}$ $\left(6 \times 10^{9}-8 \times 10^{9} \mathrm{cells} / \mathrm{ml}\right)$ of bacterial culture in mixed conditions. The control group (A) of mice received only $0.1 \mathrm{ml}$ of nutrient broth. The animals were scarified by decapitation at the 7th, 14th, 21st, 30th days of post inoculation.

\section{Bacterial culture}

The pure culture of bacteria, two fluorescent pseudomonads $\left(\mathrm{R}_{1}\right.$ and $\left.\mathrm{R}_{2}\right)$ and aeromonad $\left(\mathrm{R}_{3}\right)$ isolated from ulcer tissues of Anabas testudineus were maintained routinely on agar slants and in nutrient broth [Pepton (Difeo)-10.0gm, Beef extract (Difeo)-100gm, Sodium Chloride-3gm, Distilled Water-1000ml, Nutrient Agar-2\%]. The subcultures of pure and mixed were performed in nutrient broth when required.

\section{Histological study}

At the termination of the experimentnt, body weights of individual mice in all the experimental groups were recorded. At the time of autopsy, the spleen and lymph nodes of control and inoculated mice were quickly dissected out, weighted and fixed in aqueous Bouin's solution for regular histological examinations. A small portion of fresh spleen was cut into pieces and its impression was taken on a grease free slides. Then the slides were stained with Giemsa and carbol fuchsin. The Bouin's fixed tissues of spleen and lymph nodes were processed and sections were prepared at $6 \mu \mathrm{m}$ in thickness. All the sections were stained by haematoxylin-eosin staining procedure. From the well-stained sections, observations were made under compound light microscope and photomicrographs were also taken.

\section{Statistical analysis}

Significance tests between pair of means for control and treated groups was determined by student's t-test. The data are expressed as mean \pm standard error of six mice and the level of significance considered were $p<0.001$.

\section{Results and Discussion}

The present study indicates fish pathogenic bacteria on mice that may have some effects on the spleen and lymph nodes.

Table I shows body weight and relative spleen weight in control and bacteria treated experimental mice during 30 days study period. Time exposure showed no significant differ- ence in body weight between control and treated mice but the value showed a tendency towards increment. Spleen weight was increased significantly $(p<0.001)$ at 14 th and 21 st days of post treated mice.

Table I: Effect of Aeromonas hydrophilia on the body weight and relative spleen weight of male mice following 7th, 14th, 21st and 30th day post exposure.

\begin{tabular}{l|c|c}
\hline Groups & Body weight (g) & $\begin{array}{c}\text { Relative spleen } \\
\text { weight (g) }\end{array}$ \\
\hline (A) Control (6)* & $20.78 \pm 1.29 * *$ & $1.90 \pm 0.12$ \\
(B) 7 days (6) & $21.47 \pm 1.12$ & $2.02 \pm 0.26$ \\
(C) 14 days (6) & $23.48 \pm 1.09$ & $2.97 \pm 0.05^{* * *}$ \\
(D) 21 day (6) & $23.96 \pm 0.95$ & $3.00 \pm 0.14 * * *$ \\
(E) 30 days (6) & $24.11 \pm 0.63$ & $3.29 \pm 0.72$ \\
\hline
\end{tabular}

* No. of animals

** Mean \pm standard error

$* * *$ level of significance $(p<0.001)$

The basic structure of the control spleen is a network of reticular cells in which erythrocytes, leucocytes, pigment cells and a widely ramified system of blood vessels are embedded. Control spleen showed encapsulation with a thick fibrous layer which at some places invaginates to form distinct trabeculae, white pulps are surrounded by the red pulps in the parenchymal spleen. Other lymph-nodes were also covered by a capsule and trabeculae that divide the cortex. The cortical nodules often showed germinal layer which lightens stain and lymphocytes were observed.

In treatment group severe haemorrhage and swelling were observed at the site of injection. Spleen and lymph-nodes showed various degrees of histopathological changes after inoculation with mixed culture of bacteria. Bacteria were seen on impression of sliced spleen of experimentally infected mice (Fig. 1). Experimental mice necrosis revealed congestion of the spleen and lymph nodes. The spleen was congested and loss of definition of the red and white pulps was observed at 7 th. The size of the cells in the germinal centres tends to be larger than the control spleen and few of them could be seen in divisional stages. Transformation of white pulp into germinal centres (GC) was also observed in lymphnodes during 7 th day of inoculation of bacteria. Mild atrophy in spleenic corpuscles with numerous macrophages was seen 
within the sinusoid of spleen in the 7 th day of inoculation.

Spleen after 14th days of inoculation showed distinct and compact germinal centres with lymphocytes of various stages of blast transformation (Fig. 2). The spleen after inoculation of 14th and 21 st days (Fig. 3) showed vaculation in the white pulp region. Haemorrhages and necrosis were also observed at certain regions of spleen both at the 14th and 21 st days of inoculation of bacteria. (Fig. 4, 5).

In lymph-nodes also prominent germinal with lymphocyte centres were seen in the 14 th and 21 st days of inoculation. Besides depletion of lymphoid cells necrosis were also prominent in the lymph nodes of 7th, 14th and 21st (Fig. 6) days of inoculation of this bacteria.
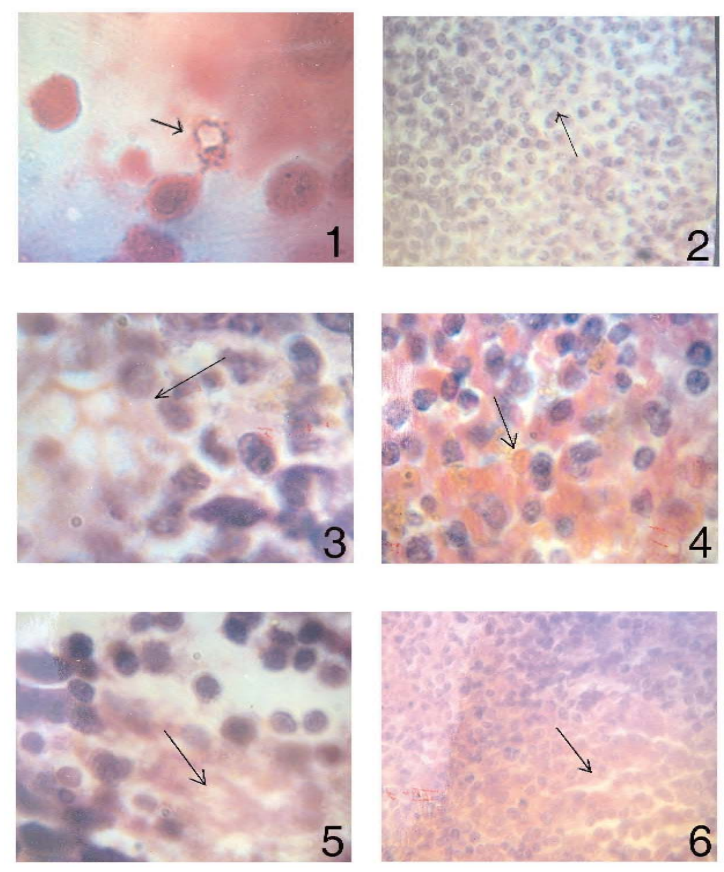

Fig. 1: Impression smear preparation of spleen of mixed culture treated mice showing bacteria .

Fig. 2: Showing germinal centre in the spleen after 14th day of inoculation of bacteria.

Fig. 3: Showing distinct germinal centre and some vaculation in the white pulp region in the spleen of 21st day of inoculation of bacteria.

Fig. 4: Showing hemorrhages at certain region in the spleen of 21st day of inoculation of bacteria.

Fig. 5: A part of spleen showing necrosis after 21st day of inoculation of bacteria.

Fig. 6: Showing necrosis at lymphoid organ of mice after 21 st day of inoculation of bacteria.
It is evident that various types of histopathological changes in spleen and other lymph- nodes of mice infected with mixed culture of bacteria in the experiments. The spleen was congested and loss of definition of the red and white pulps. The size of the cells in the germinal centres tends to be larger than control spleen and few of them could be seen in divisional stages. Transformation of white pulp into germinal centres (GC) was also observed in lymph-nodes after inoculation of bacteria. Mild atrophy in spleenic corpuscles with numerous macrophages was seen within the sinusoid of spleen in the present study. But Corrin (1980) observed that the lungs of human bacterial-shock victims are the most frequently damaged organs. The liver of infected mice showed focal parenchymal necrosis and swelling of Kupffer cells, both of which may be caused by bacterial endotoxin (Levy and Ruebner, 1967). Filkins (1969) suggested that long and severe endotoxaemia impairs liver function by damaging the vasculature.

Vacuolation and necrosis were also noted in fish infected by the same bacteria (Pradhan, 1991) reported regressive changes such as necrosis of kidney and spleen tissues after inoculation of healthy carps with pathogenic Aeromonas. Miyazaki and Kaige (1985b) observed the manifestation of similar pathological signs in crucian carps with motile aeromonad. Wiklund and Bylund (1990) observed various histopathological changes incertain fishes with Pseudomonas anguilliseptica. They also reported accumulation of eosinophilic materials in the tubular lumen in fishes with the highest concentration of bacteria.

It is obvious from the present study that mice treated with mixed culture of two fluorescent pseudomonads and an aeromonad showed vaculation and necrosis. Marco et al. (1991) recorded the inflammation, necrosis and depletion of lymphoid cells, 5-6 days after inoculation in albino mice injected with Listeria. Bayo et al. (1980) experimentally injected the mice by $P$. areuginosa and found lesions in kidney, spleen and liver. They further reported that the frequency of the type and the time of appearance of the lesions depend on the dose of organs, individual susceptibility of the mouse and the number of injections. Mc Callum et al. (1982) studied the effect of pure and mixed culture of anaerobic infections with Bacteriodes melaninogenicus and Fusobacteriu necrophorum in mice and encountered a severe infection progressed in mice infected with mixture of anaerobic bacteria, whereas no infection showed when either of the organisms was injected alone. Above mentioned results depict the damaging nature of the immuno-responsive tissues to the pathogenesis of Aeromonas hydrophilia infection in the mice.

\section{Acknowledgement}

Authors are grateful to Late Dr. K. Pradhan, Lecturer, Darjeeling Government College, W.B., India and Prof. C. K. 
Manna, Department of Zoology, University of Kalyani, W.B., India for extending laboratory facilities during this research work.

\section{References}

Bayo S., Petit J. C. and Sicard D. (1980). Histopathological observations of experimental hematogenous infection with Pseudomonas aeruginosa in mice. Pathol. Biol., 28(4): 241-246.

Camin J. H. (1948). Mite transmission due to hemorrhagic septicemia in snake. J. Parasitol., 34: 345-354.

Chopra A. K., Xu, X.-J., Ribardo D., Gonzalez M., Kuhl K. Peterson J. W. and Houston C. W. (2000). The Cytotoxic Enterotoxin of Aeromonas hydrophila Induces Proinflammatory Cytokine Production and Activates Arachidonic Acid Metabolism in Macrophages. Infect. Immun., 68(5): 2808-2818.

Corrin B. (1980). Lung pathology in septic shock. J. Clin. Pathol., 33: 891-894.

Cusick P. K. and Bullock B. C. (1973). Ulcerative dermatitis and pneumonia associated with Aeromonas hydrophila infection in bottle nosed dolphin. J. Am. Vet. Med. Assoc., 163: 578-579.

Filkins J. P. (1969). Hepatic vascular response to endotoxin. Proc. Soc. Exp. Biol. Med., 131: 1235-1238.

Harris K. K., Gupta A. K. and Agarwal S. M. (1992). Pathophysiology of epizootic ulcerative syndrome in Channa punctatus. J. Parasito. Appl. Animal Biol., 1: 125-130.

Hey wood R. W. (1968). Aeromonas injection in snakes. Cornell Vet., 58: 236-241.

Huizinga H. W., Esch G. W. and Hazen T. C. (1979). Histopathology of red-sore disease (Aeromonas hydrophila) in naturally and experimentally infected largemouth bass Micropterus salmoides (Lacepede). $J$. Fish Dis., 2:263-277

Ketover B. P., Young L. S. and Armstrong D. (1973). Septicemia due to Aeromonas hydrophila: clinical and immunologic aspects. J. Infect. Dis., 127: 284-290.

Lai X. H., Xu J. G. and Liu B. Y. (1991). Experimental injection of specific pathogen free mice with enterohemorrhagic Escherichia coli 0157:H7. Microbiol. Immunol., 35(7): 515-524.

Levy E. and Ruebner B. H. (1967). Hepatic changes produced by a single dose of endotoxin in the mouse. Light microscopy and histochemistry. Am. J. Pathol., 51: $269-285$.
Ljungh A. and Kronevi T. (1982). Aeromonas hydrophila toxinsintestinal fluid accumulation and mucosal injury in animal models. Toxicon, 20: 397-407.

Macro A. J., Domingo M. I., Parts, M., Briones V., Pumarola, M. and Dominguez, L. (1991) Pathogenesis of lymphoid lesions in marine experimental Listeriosis. $J$. Comp. Pathol., 105: 1-15.

Mc Callum R. E., Rohrer M. D., Urbaschek R. and Urbaschek B. (1982). Histopathology of mixed anaerobic intraabdominal infection in mice. Wien. Klin. Wochenschr., 60: 702-704.

Miyazaki T. and Kaige N. (1985b). Comparative histopathology of Edwardsiellosis in fishes. Fish Pathol., 20: 219227.

Pal J. and Pradhan K. (1990). Bacterial involvement in ulcerative condition of air breathing fish from India. J. Fish Biol., 36: 333-339.

Pierce R. L., Daley C. A., Gates C. E. and Wohlgemuth K. (1973). Aeromonas hydrophilia Septicemia in dog. J. Am. Vet. Med. Assoc., 161: 469.

Pradhan K., Pal J. and Das A. (1991). Ulcerative fish disease in Indian major carps: Isolation of bacteria from ulcers. Environ. Ecol., 9(2): 510-515.

Price S. B. and Mc Callum, R. E. (1987). Studies on bacterial synergism in mice infected with Bacteroides intermedius and Fusobacterium necrophorum. J. Basic Microbiol., 27(7): 377-386.

Rigney M. M., Zilinsky J. W. and Rouf M. A. (1978). Pathogenicity of Aeromonas hydrophila in red leg disease in frogs. Curr. Microbiol., 1: 175-1 79.

Roberts R. J. (1978). Fish pathology. Bailliere Tindall, London.

Shoots Jr. E. B., Gaines J. L., Martin Jr. L. and Prestwood A. K. (1972). Aeromonas induced deaths among fish and reptiles in an eutrophic inland lake. J. Am. Vet. Med. Assoc., 161: 603-607.

Ventura M. T. and Grizzle J. M. (1988). Lesions associated with natural and experimental infections of Aeromonas hydrophila in channel catfish, Ictalurus punctatus (Rafinesque). J. Fish Dis.. 11: 397 - 407.

Wiklund T. and Bylund G. (1990). Pseudomonas anguilliseptica as a pathogen of salmonid fish in Finland. Dis. Aquat. Org., 8: 13-19.

Wohlgemith K., Pierce R. L. and Kirkbride C. A. (1972). Bovine abortion associated with Aeromonas hydrophilia. J. Am. Vet. Med. Assoc., 160: 1001-1002.

Received:December 12, 2010;

Accepted: May 09, 2011 